\title{
Strategi Pemasaran Benih Padi Studi Kasus Di PT Bcg (Persero) UBR V Kabupaten Lampung Timur
}

\section{Rice Seed Marketing Strategy Case Study at PT Bcg (Persero) UBR V, East Lampung Regency}

\author{
Dina Aprianti ${ }^{*}$, Nurman Abdul Hakim ${ }^{1}$, Dayang Berliana ${ }^{2}$ \\ ${ }^{1}$ Jurusan Budidaya Tanaman Pangan / Politeknik Negeri Lampung \\ 2 Jurusan Ekonomi dan Bisnis / Politeknik Negeri Lampung \\ Email : dinaaprianti03@gmail.com
}

\begin{abstract}
The author's goal is to identify internal factors in the form of strengths and weaknesses as well as external factors in the form of opportunities and threats in marketing rice seeds at PT BCG, analyzing the marketing strategies of rice seeds most appropriate to achieve the sales volume of rice seeds and expanding the distribution area at PT BCG. The data used are of two types, namely quantitative and qualitative data obtained directly. Results and discussion concluded that internal factors affecting rice seed marketing included strength factors, namely large land area and weaknesses, namely the number of human resources in production which were still lacking and were still done manually, while external marketing factors for opportunity factors were good support from surrounding communities in seed business for the welfare of farmers as consumers and the threat factor is competitors in the same business. Companies need to collaborate with fellow producers in meeting the needs of consumers, the company applies friendly and courteous servicesto consumers, the company needs the application of agricultural tools in producing seeds, the company needs to open a branch selling new products, the company is able to increase business capital, and the company uses packaging that is not easily damaged and airtight material (polyethylene plastic). determining the value or weight rating for strengths of 0.21 , then weaknesses of 0.09 then opportunities of 0.26, and threats of 0.14.
\end{abstract}

Keywords : Marketing Strategy, IFAS, EFAS, SWOT

Disubmit: 10 Januari 2019 Diterima: 24 Februari 2019 Disetujui: 19 Maret 2019

\section{PENDAHULUAN}

Tanaman pangan merupakan subsektor yang sangat penting bagi Indonesia bahkan dunia. Terdapat banyak jenis tanaman yang tergolong dalam tanaman pangan salah satunya adalah tanaman padi. Tanaman padi yang kemudian menghasilkan beras, merupakan bahan pangan pokok bagi penduduk Indonesia yang memberikan energi dan zat gizi yang tinggi. Beras telah menjadi komoditas strategis dalam kehidupan bernegara di Indonesia karena dapat mempengaruhi stabilitas ekonomi melalui inflasi (gejolak harga) dan stabilitas nasional (gejolak sosial) (Kusnanto dan Khaswarina, 2016).

Indonesia mevmiliki sentra produksi padi yang tersebar di beberapa wilayah nusantara. Penyebaran produksi padi, baik padi sawah dan padi ladang, diseluruh Indonesia menunjukkan terkonsentrasinya produksi padi hanya pada pulau tertentu (Hardiyanti dkk, 2010). 
Aprianti Dina dkk : Strategi Pemasaran Benih Padi Studi Kasus Di PT Bcg (Persero)........

Tabel 1. Data produksi, luas panen, dan produktivitas di sepuluh sentra padi di Indonesia 2017-2018

\begin{tabular}{|c|c|c|c|c|c|c|c|}
\hline \multirow[b]{2}{*}{ No } & \multirow[b]{2}{*}{ Provinsi } & \multicolumn{3}{|c|}{ Tahun 2017} & \multicolumn{3}{|c|}{ Tahun 2018} \\
\hline & & $\begin{array}{l}\text { Produksi } \\
\quad \text { (ton) }\end{array}$ & $\begin{array}{c}\text { Luas } \\
\text { panen } \\
(\mathrm{Ha})\end{array}$ & $\begin{array}{c}\text { Produk- } \\
\text { tivitas } \\
\text { (ton/ha) }\end{array}$ & $\begin{array}{l}\text { Produksi } \\
\quad \text { (ton) }\end{array}$ & $\begin{array}{c}\text { Luas } \\
\text { panen } \\
(\mathrm{Ha})\end{array}$ & $\begin{array}{c}\text { Produk- } \\
\text { tivitas } \\
\text { (ton/ha) }\end{array}$ \\
\hline 1. & Jawa Timur & 12.432 .793 & 2.136 .412 & 58.19 & 12.367 .414 & 2.110 .625 & 58.60 \\
\hline 2. & Jawa Barat & 11.849 .636 & 1.987 .751 & 59.61 & 12.090 .951 & 2.023 .421 & 59.75 \\
\hline 3. & $\begin{array}{l}\text { Jawa } \\
\text { Tengah }\end{array}$ & 11.067 .247 & 1.933 .627 & 57.24 & 11.052 .782 & 1.878 .293 & 58.84 \\
\hline 4. & $\begin{array}{l}\text { Sulawesi } \\
\text { Selatan }\end{array}$ & 5.988 .416 & 1.168 .479 & 51.25 & 6.124 .408 & 1.142 .608 & 53.60 \\
\hline 5. & $\begin{array}{l}\text { Sumatera } \\
\text { Utara }\end{array}$ & 4.669 .778 & 864.283 & 54.03 & 4.847 .748 & 907.265 & 53.43 \\
\hline 6. & $\begin{array}{l}\text { Sumatera } \\
\text { Selatan }\end{array}$ & 4.807 .430 & 953.554 & 50.42 & 4.971 .087 & 970.204 & 51.24 \\
\hline 7. & Lampung & 4.090 .654 & 789.322 & 51.82 & 4.254 .185 & 806.353 & 52.76 \\
\hline 8. & $\begin{array}{l}\text { Sumatera } \\
\text { Barat }\end{array}$ & 2.810 .425 & 533.399 & 52.69 & 2.726 .075 & 525.249 & 51.90 \\
\hline 9. & $\begin{array}{l}\text { Kalimantan } \\
\text { Selatan } \\
\text { Nusa }\end{array}$ & 2.258 .260 & 506.823 & 44.56 & 2.351 .356 & 525.209 & 44.77 \\
\hline 10. & $\begin{array}{l}\text { Tenggara } \\
\text { Barat }\end{array}$ & 2.189 .044 & 427.783 & 51.17 & 2.296 .854 & 434.492 & 52.86 \\
\hline
\end{tabular}

Sumber: Kementerian Pertanian, 2018

Pada Tabel 1 tingginya produksi padi di Pulau Jawa tersebut disebabkan oleh tingginya produktivitas dan luas panen dibandingkan pulau - pulau lainnya. Produksi padi provinsi Lampung menempati urutan ketujuh di Indonesia dengan jumlah produksi pada tahun 2018 sebanyak 4.254.185 ton. Usahatani padi di Lampung tidak lepas dari peranan perusahaan perbenihan. Permasalahan yang dihadapi yaitu produsen telah memiliki distributor tetap untuk menyalurkan benih kepada konsumen, tetapi dalam pendistribusian benih diantaranya yaitu pembayaran petani yang lama menyebabkan distribusi benih padi bersubsidi tertunda. Hal ini yang membuat ketersediaan stok untuk memenuhi pasar dengan produsen lokal, dan jadwal tanam yang berbeda untuk beberapa daerah sehingga perlu dilakukan seleksi jadwal tanam yang tercantum dalam DUPBB (Daftar Usulan Pendistribusian Benih Padi Bersubsidi) selanjutnya pendistribusian didahulukan pada daerah yang jadwal tanamnya lebih dahulu.

Produsen benih untuk mendapatkan suatu produk menjalin kerjasama dengan para petani mulai dari produksi hingga distribusi oleh karena itu setiap produk akan adanya perbedaan dalam hal kualitas benih yang dihasilkan maka dari itu perlu adanya strategi pemasaran yang bertujuan memberikan kepuasan kepada pembeli dan masyarakat yang lain dalam pertukarannya untuk mendapatkan sejumlah laba atau perbandingan antara penghasilan dan biaya yang menguntungkan.

Perkembangan bisnis di perusahaan perbenihan belakangan ini semakin lama semakin menonjol akan kompleksitas, persaingan, perubahan, dan ketidakpastian. Keadaan ini menimbulkan persaingan yang tajam antara perusahaan, baik karena pesaing yang semakin bertambah, volume produk yang semakin meningkat, maupun bertambah pesatnya perkembangan teknologi (Prawitasari, 2010). Setiap perusahaan melakukan penjualan produk benih padi varietas 
ciherang yang memiliki kualitas dan kelas benih ES yang sama hal ini bukanlah hal yang mudah untuk memasarkan produk yang sama seperti yang di ketahui PT Pertani, Fa Bandul Besi, dan PB Pakde Tani Jaya merupakan pesaing bagi perusahaan PT BCG dan sehingga perlu adanya analisis strategi pemasaran. Tujuan penelitian ini ialah mengidentifikasi faktor - faktor internal berupa kekuatan dan kelemahan serta faktor- faktor eksternal berupa peluang dan ancaman dalam pemasaran benih padi pada PT BCG dan menganalisis strategi pemasaran benih padi paling tepat untuk mencapai volume penjualan benih padi dan memperluas wilayah distribusi pada PT BCG.

\section{METODE PENELITIAN}

Penelitian dilaksanakan pada bulan Februari 2019 berdasarkan data yang diperoleh dari hasil indepth interview dengan karyawan perusahaan di PT BCG. Responden dalam penelitian ini berjumlah 24 orang terdiri dari pimpinan (1) orang, karyawan (5) orang, Distributor (6) orang, Penangkar (6) orang dan konsumen (6) orang. Metode pengolahan dan analisis data yang akan digunakan dalam penelitian ini adalah metode deskriptif dengan pendekatan konsep manajemen strategi pemasaran dengan memperhitungkan perubahan lingkungan internal dan eksternal perusahaan. Pada penelitian ini metode deskriptif yang digunakan adalah metode studi kasus, sehingga kesimpulan yang diambil akan tetap terkait dengan perusahaan. Langkah awal yang dilakukan adalah mengidentifikasi faktor internal dan eksternal dengan menggunakan matriks IFE dan EFE. Identifikasi faktor internal dan eksternal perusahaan

Langkah awal yang dilakukan adalah mengidentifikasikan faktor internal yaitu dengan mendaftarkan semua kelemahan dan kekuatan organisasi. Kemudian dilakukan identifikasi faktor eksternal perusahaan dengan melakukan pendaftaran semua peluang dan ancaman organisasi. Daftarkan peluang terlebih dahulu, kemudian ancaman organisasi. Selanjutnya dilakukan penentuan bobot dan rating serta terakhir penentuan matriks SWOT.

\section{HASIL DAN PEMBAHASAN}

Kuesioner yang diajukan kepada responden berdasarkan perencanaan strategi analisis SWOT (Strenght, Weaknesses, Opportunities, dan Threats). Faktor Kekuatan terdiri dari lokasi perusahaan yang strategis, benih yang diproduksi berkualitas, harga yang terjangkau, terjalin kerjasama yang baik dengan petani penangkar, pelayanan yang sopan dan ramah, lahan yang luas, sudah memiliki kurang lebih 50 pelanggan tetap perusahaan, sarana dan prasarana pemasaran yang lengkap, produksi yang selalu meningkat, menciptakan produk yang baru, menghasilkan benih padi bermacam label, merek produk memakai nama perusahaan, pengawasan mutu secara ketat dari proses produksi sampai tahap akhir sertifikasi benih oleh bpsb, kebersiham gudang yang selalu terjaga. Faktor kelemahan yakni adanya karyawan yang sering terlambat, kesulitan dalam menjumlahkan produksi benih padi, saluran distribusi masih sekitar lampung, pencapaian target penjualan belum stabil, sistem pembayaran produk yang terlambat, bentuk kemasan produk kurang menarik, kurangnya dana sebagai sumber daya modal bagi perusahaan, banyaknya varietas padi ciherang yang dijual dipasaran, produk tidak dapat disimpan terlalu lama, permintaan konsumen sering tidak sesuai dengan stok yang ada, kurangnya peralatan untuk proses produksi benih padi salah satunya adalah box dryer, jumlah sdm dalam produksi yang masih kurang dan masih dikerjakan secara manual.

Faktor peluang ialah adanya kerjasama yang baik dengan perusahaan lain pangsa pasar yang luas, permintaan konsumen yang tinggi, layanan membeli produk dengan cara online, kualitas produk diakui konsumen, memanfaatkan teknologi untuk promosi, kemampuan distribusi yang cepat, terbukanya pemasaran luar negri, dukungan yang baik dari masyarakat sekitar dalam usaha 
benih untuk mensejahterahkan petani sebagai konsumen. Faktor ancaman yaitu pesaing yang bergerak usaha yang sama, konsumen yang beralih ke perusahaan lain, pesaing yang memberikan harga miring, ketatnya persaingan dan promosi yang dilakukan, kondisi cuaca dan iklim yang tidak stabil, penetapan harga maksimum oleh pemerintah yang seringkali berubah-ubah, selera konsumen yang cepat berubah, kepercayaan konsumen yang berkurang, harga jasa pengangkutan barang dari produsen ke konsumen meningkat, tawar menawar antara distributor dengan konsumen sangat tinggi, pengadaan dan penyaluran benih subsidi yang tidak sehat, penggunaan benih padi varietas baru masih relatif rendah. Berdasarkan hasil pengolahan dapat diketahui hasil sebagai berikut.

Pada Tabel 4 dapat dijelaskan bahwa skor bobot pada matriks SWOT menunjukkan jika 1,00 sampai 1,99 menunjukkan internal lemah, 2,00 sampai 2,99 sedang, 3,00 sampai 4,00 adalah kuat Anwar (2017), maka dapat dinyatakan bahwa SO memiliki bobot nilai sebesar 3,99 artinya faktor kekuatan- peluang menunjukkan internal dan eksternal kuat, bobot nilai ST sebesar 3,37 artinya faktor kekuatan-kelemahan menunjukkan kuat, bobot nilai WO sebesar 2,45 artinya faktor kelemahan-peluang menunjukkan sedang, dan bobot nilai WT sebesar 1,83 artinya faktor kelemahan- ancaman menunjukkan lemah.

Tabel 4. Penentuan Bobot Nilai Matriks SWOT

\begin{tabular}{|ll|lllll|}
\cline { 2 - 6 } \multicolumn{1}{l|}{} & O & $\mathbf{1 , 8 1}$ & T & $\mathbf{1 , 1 9}$ \\
\hline $\mathbf{S}=$ & $\mathbf{2 , 1 8}$ & SO & 3,99 & ST & 3,37 \\
$\mathbf{W}=$ & $\mathbf{0 , 6 4}$ & WO & 2,45 & WT & 1,83 \\
\hline
\end{tabular}

Hasil dari penentuan bobot nilai matriks SWOT di atas nilai faktor internal pada kekuatan lebih besar dibandingkan kelemahan serta dari faktor eksternal nilai peluang lebih besar dibandingkan ancaman, hal ini perusahaan dapat mencapai volume penjualan yang tinggi dengan adanya penambahan sumber daya manusia dan memperluas pangsa pasar.

Untuk menentukan posis kordinat kuadran produsen, dapat dicari dengan cara menghitung selisih dari total faktor kekuatan dengan total faktor kelemahan, kemudian dihitung juga selisih dari total skor peluang dengan total skor ancaman sebagai berikut:

IFAS $=$ Total skor kekuatan - total skor kelemahan

$$
\begin{aligned}
& =2,18-0,64 \\
& =1,54 \mathrm{x}
\end{aligned}
$$

EFAS $=$ Total skor peluang - total skor ancaman

$$
\begin{aligned}
& =1,81-1,19 \\
& =0,62 \mathrm{y}
\end{aligned}
$$

Hasil dari semua faktor tersebut kemudian dapat digambarkan dalam kuadran SWOT sebagai berikut : 


\section{Peluang $(1,81)$}

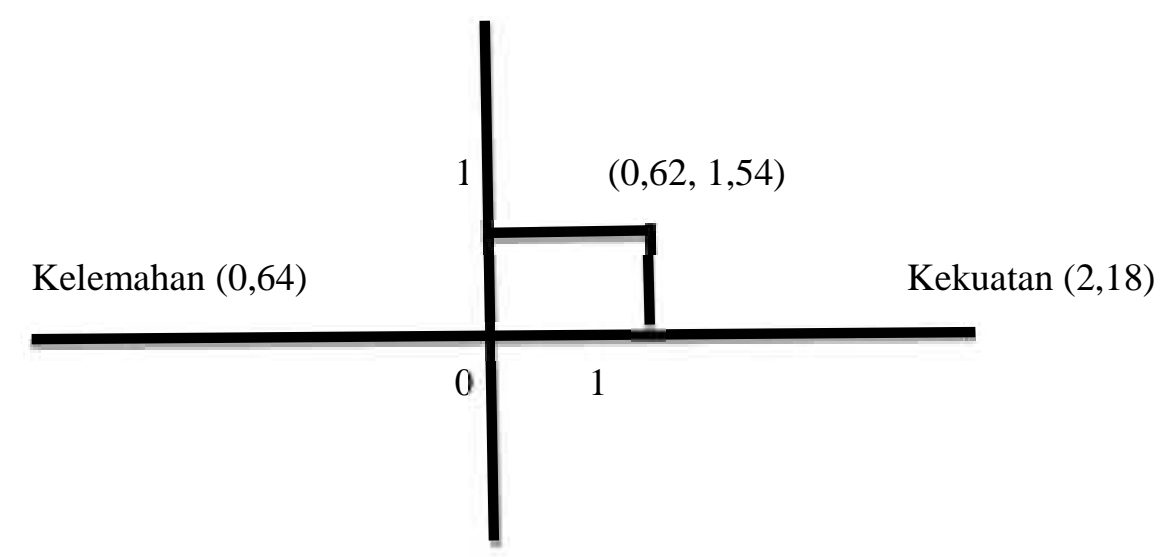

Ancaman $(1,19)$

Gambar 1. Posisi Produsen Benih dalam kuadran SWOT

Berdasarkan kuadran SWOT berada pada kuadran 1 (progresif), yang artinya menunjukkan bahwa usaha produsen benih memiliki kekuatan yang baik yang dapat di manfaatkan sebagai peluang dalam mendorong dalam kemajuan usaha.

Berdasarkan hasil persilangan diperoleh alternatif strategi pemasaran yaitu :

Berdasarkan strategi SO

Untuk memenuhi kebutuhan benih yang tinggi akan tetapi perusahaan tidak memiliki stok yang dibutuhkan maka dari itu perusahaan perlu melakukan kerjasama dengan sesama produsen agar saling menguntungkan dan tidak berpindahnya konsumen ke pesaing. Perusahaan menerapkan pelayanan yang ramah dan sopan kepada konsumen agar loyalitas semakin bertambah. Perusahaan perlu adanya penerapan alat-alat pertanian agar dalam melakukan produksi hingga benih dikemas agar benih yang ingin di capai oleh perusahaan sesuai yang ditargetkan dan proses yang dilakukan tidak terlalu lama. Perusahaan perlu membuka cabang penjualan produk baru untuk mendapatkan pangsa pasar yang luas dan terkenalnya produk oleh konsumen. Perusahaan mampu meningkatkan modal usaha untuk menambah skala produksi yang ingin dicapai dalam memenuhi kebutuhan benih konsumen yang tinggi. Perusahaan menggunakan kemasan yang tidak mudak rusak dan bahan kedap udara (plastik polyethylene) untuk menghindar kerusakan kualitas benih.

Berdasarkan strategi WO Perusahaan harusnya memberikan peringatan kepada karyawan yang sering terlambat agar tercapainya suatu visi dan misi perusahaan melakukan desain kemasan produk yang menarik agar calon konsumen mudah mengenal produk produsen dan kemasan juga dapat memberikan suatu informasi tentang produk yang dijual melakukan pemesanan benih sebelum jadwal tanam untuk menghindarkan ketersediaan benih yang tidak ada atau produksi yang berlebihan. Perusahaan harus mempertahankan kualitas produk secara konstan agar konsumen tetap membeli produk yang dipasarkan oleh konsumen Perusahaan dalam melakukan penyimpanan benih yang sesuai dengan suhu dan kelembaban agar vigor dan viabilitas pada benih tidak mudah rusak ketika ingin ditanam. Untuk menciptakan produk yang berkualitas dan ketidaktahuan terhadap benih bersertifikasi perusahaan perlu mengadakan penyuluhan kepada petani

Berdasarkan strategi ST Perusahaan dalam mendistribusikan benih secara cepat dan bebas biaya pengiriman untuk wilayah terdekat, banyaknya pesaing baru yang menjual produk yang sama yaitu benih varietas Ciherang maka perusahaan harus mampu bersaing dengan cara meningkatkan kualitas produk yang lebih unggul dari pesaing, memasarkan produk secara lebih luas, dan 
memberikan garansi terhadap produk yang dibeli oleh konsumen. Perusahaan memberikan garansi terhadap produk yang dibeli perusahaan perlu menambah ketenagakerjaan/ kerjasama dengan penangkar benih untuk meningkatkan produksi yang lebih besar sehingga mampu memenuhi kebutuhan benih konsumen.

Berdasarkan strategi WT perusahaan perlu menerima pemesanan benih lebih awal sebelum jadwal tanam dilakukan agar konsumen dapat melakukan pembayaran secara mencicil yang artinya keluhan produsen terhadap konsumen yaitu pembayaran produk yang sering terlambat sehingga menghambat lajunya distribusi benih yang ingin disalurkan kepada konsumen lainnya maka dari itu perlu adanya pencegahan agar tidak menimbulkan kerugian bagi produsen yaitu memberikan jangka waktu pembayaran kepada konsumen agar tidak hilangnya pelanggan. Untuk mencapai volume penjualan benih padi dan memperluas wilayah distribusi maka perusahaan hendaknya melakukan strategi promosi yang paling tepat dapat menggunakan media sosial, media cetak, dan penjualan pribadi (Personal selling) yang berupa demplot yaitu mendatangkan ke rumah warga gabungan kelompok tani lalu meminjam lahan kosong disekitar rumah warga untuk membuktikan kualitas produk benih yang akan ditanam. Perusahaan menawarkan produk yang sesuai dengan keinginan konsumen, sebelum memproduksi benih padi maka produsen perlu melakukan survei terlebih dahulu dengan cara mengumpulkan konsumen atau kelompok tani produk apa yang ingin di tanam oleh konsumen .

Perusahaan dalam menetapkan harga tentunya yang sesuai dengan pasaran yaitu harga benih merupakan faktor penentu keberhasilan suatu usaha produsen untuk itu perlu adanya pertimbangan harga jual yang sesuai dengan kualitas produk sehingga para konsumen akan mempercayainya dan tidak mudah terpengaruhi harga murah dari pesaing. Produsen mampu memberikan informasi terhadap konsumen apabila adanya biaya tambahan terhadap pengangkutan barang ke konsumen.

Perusahaan harus mampu menjaga hubungan yang baik terhadap mitra maupun konsumen, yaitu hubungan komunikasi dan saling silaturahmi tetap terjaga antara penangkar mengingat bahwa produsen untuk mendapatkan benih melakukan kerjasama dengan penangkar dan kepada konsumen selalu komunikasi untuk mengetahui terhadap kepuasan produk yang di pakai sehingga apabila adapun keluhan terhadap produk maka produsen benih dapat memperbaiki untuk selanjutnya.

\section{KESIMPULAN DAN SARAN \\ Kesimpulan}

Berdasarkan pembahasan yang telah dilakukan, maka dapat disimpulkan bahwa :

Lokasi perusahaan yang strategis, benih yang diproduksi berkualitas, harga yang terjangkau, terjalin kerjasama yang baik dengan petani penangkar, pelayanan yang sopan dan ramah, lahan yang luas, sudah memiliki kurang lebih 50 pelanggan tetap perusahaan, sarana dan prasarana pemasaran yang lengkap, produksi yang selalu meningkat, menciptakan produk yang baru, menghasilkan benih padi bermacam label, merek produk memakai nama perusahaan, pengawasan mutu secara ketat dari proses produksi sampai tahap akhir sertifikasi benih oleh bpsb, kebersihan gudang yang selalu terjaga, adanya karyawan yang seing terlambat, kesulitan dalam melakukan jumlah produksi benih padi, saluran distribusi masih sekitar lampung, pencapain target penjualan belum stabil, sistem pembayaran produk yang terlambat, bentuk kemasan produk kurang menarik, kurangnya dana sebagai sumber daya modal bagi perusahaan, banyaknya varietas padi ciherang yang dijual dipasaran, produk tidak dapat disimpan terlalu lama, permintaan konsumen sering tidak sesuai dengan stok yang ada, kurangnya peralatan untuk proses produksi benih padi salah satunya 
adalah box dryer, jumlah sdm dalam produksi yang masih kurang dan masih dikerjakan secara manual, adanya kerjasama yang baik dengan perusahaan lain, pangsa pasar yang luas, permintaan konsumen yang tinggi, layanan membeli produk dengan cara online, kualitas produk diakui konsumen, memanfaatkan teknologi untuk promosi, kemampuan distribusi yang cepat, terbukanya pemasaran luar negri, dukungan yang baik dari masyarakat sekitar dalam usaha benih untuk mensejahterahkan petani sebagai konsumen, pesaing yang bergerak usaha yang sama, konsumen yang beralih ke perusahaan lain, pesaing yang memberikan harga miring, ketatnya persaingan dan promosi yang dilakukan, kondisi cuaca dan iklim yang tidak stabil, penetapan harga maksimum oleh pemerintah yang seringkali berubah-ubah, selera konsumen yang cepat berubah, kepercayaan konsumen yang berkurang, harga jasa pengangkutan barang dari produsen ke konsumen meningkat, tawar menawar antara distributor dengan konsumen sangat tinggi, pengadaan dan penyaluran benih subsidi yang tidak sehat, penggunaan benih padi varietas baru masih relatif rendah.

Kebutuhan benih yang tinggi akan tetapi perusahaan tidak memiliki stok yang dibutuhkan maka dari itu perusahaan perlu melakukan kerjasama dengan sesama produsen agar saling menguntungkan dan tidak berpindahnya konsumen ke pesaing, perusahaan menerapkan pelayanan yang ramah dan sopan kepada konsumen agar loyalitas semakin bertambah, perusahaan perlu adanya penerapan alat-alat pertanian agar dalam melakukan produksi hingga benih dikemas agar benih yang ingin di capai oleh perusahaan sesuai yang ditargetkan dan proses yang dilakukan tidak terlalu lama, perusahaan perlu membuka cabang penjualan produk baru untuk mendapatkan pangsa pasar yang luas dan terkenalnya produk oleh konsumen, perusahaan mampu meningkatkan modal usaha untuk menambah skala produksi yang ingin dicapai dalam memenuhi kebutuhan benih konsumen yang tinggi, perusahaan menggunakan kemasan yang tidak mudak rusak dan bahan kedap udara (plastik polyethylene) untuk menghindar kerusakan kualitas benih.

\section{Saran}

Perusahaan perlu meningkatkan kualitas produk yang tidak berubah- ubah.

\section{DAFTAR PUSTAKA}

Hardiyanti,S, Hanung Ismono, dan Suriaty Situmorang, S. (2010) Analisis Efisiensi Produksi Dan Pemasaran Benih Padi Inbrida Varietas Ciherang Di Kabupaten Lampung Tengah. Universitas Lampung.

Kementerian Pertanian (2018) Statistik Konsumsi Pangan. Indonesia.

Muhammad Yusuf Anwar (2017) Strategi pemasaran kancing kerang ( shell button ) melalui analisis swot pada pt. bnb international bau-bau sulawesi tenggara. Universitas Hasanuddin. Makassar.

Kusnanto, E. M. \& S. K. (2016) 'Analisis Pemasaran Padi di Desa Raja Bejamu Kecamatan Sinaboi Kabupaten Rokan Hilir (Kusnanto, Evy Maharani \& Shorea Khaswarina)', Pekbis Jurnal, Vol 8, pp. 14-23.

Rangkuti, F. (2002) Analisis SWOT Teknik Membedah Kasus Bisnis. Jakarta: Gramedia.

Sri yati prawitasari (2010) BERDAYA SAING ( Studi pada Dealer Honda Tunggul Sakti di Semarang ). 